\title{
COWBOY JURISTS \\ and The Making of Legal ProfessionalisM
}

\author{
W. WESLEY PUE*
}

This article discusses the novelty of the concept of lawyers' professionalism in the twentieth century. The author discusses the evolution of the structure of legal professionalism in the early twentieth century, outlining the social context in which these changes occurred. Significant reforms were implemented, affecting such matters as the qualifications of lawyers, education and admission to the profession, professional ethics, and the regulatory powers of the professional organizations. The author concludes that twentieth-century professionalism in Canada emerged as a cultural project, undoubtedly influenced by political and social change, as opposed to pure market-based motivations.
Cet article porte sur la nouveauté du concept de professionnalisme des avocats au vingtième siècle. L'auteur discute de l'évolution de la structure de professionnalisme juridique au début du vingtième siècle, en donnant les grandes lignes du contexte social dans lequel ces changements se sont produits. D'importantes réformes ont été mises en place affectant, entre autres, la qualification des avocats, l'éducation et l'entrée dans la profession ainsi que la déontologie et les pouvoirs de réglementation des organismes professionnels. L'auteur conclut que le professionnalisme du vingtième siècle au Canada a émergé en tant que projet culturel, sans aucun doute influencé davantage par le changement politique et social que par des motivations purement basées sur le marché.

\section{TABLE OF CONTENTS}

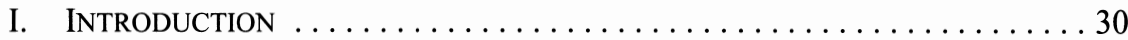

II. ThE NOVELTY OF LAWYERS' ProfESSIONALISM . . . . . . . . . . . 30

III. StRuCtures AND Cultures of LEGAL PROFESSIONALiSM $\ldots \ldots \ldots \ldots . \ldots 31$

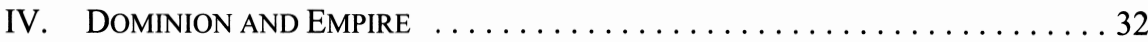

V. REMAKING CANADIAN LEgAL PROFESSIONALISM . . . . . . . . . . . . 34

VI. QUALIFICATION, EdUCATION, AND AdMISSION $\ldots \ldots \ldots \ldots \ldots \ldots \ldots . \ldots \ldots$

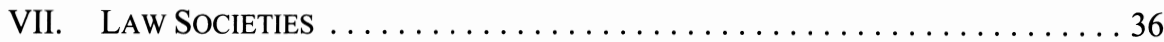

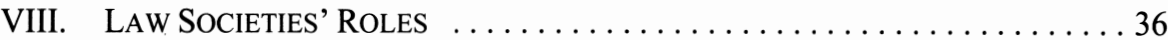

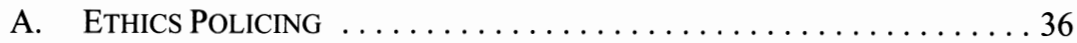

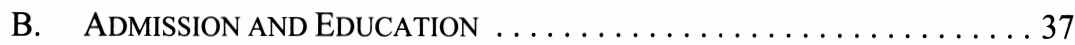

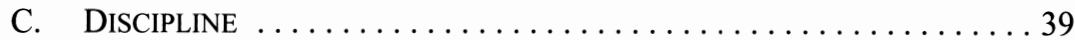

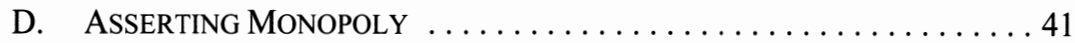

IX. RemAKing the LEgAL PROFESSION: SUMMARY $\ldots \ldots \ldots \ldots \ldots \ldots \ldots . \ldots 42$

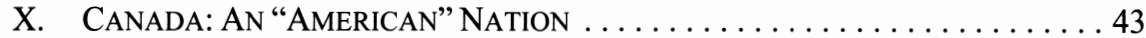

XI. OBVIOUS UnSUITABILITY of OTHER Models $\ldots \ldots \ldots \ldots \ldots \ldots \ldots \ldots$

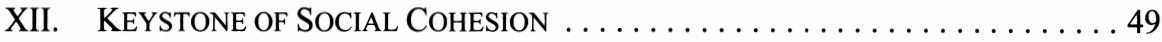

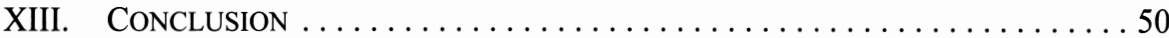

A. Theories of Professionalization $\ldots \ldots \ldots \ldots \ldots \ldots \ldots \ldots \ldots$

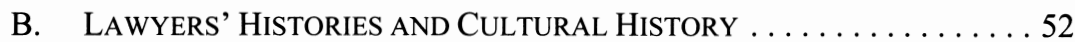

Professor, Faculty of Law, University of British Columbia. This is a modified version of W. Wesley Pue, "Cultural Projects and Structural Transformation in the Canadian Legal Profession" in W. Wesley Pue \& David Sugarman, eds., Lawyers and Vampires: Cultural Histories of Legal Professions (Portland, Or.: Hart, 2003) 367. 


\section{INTRODUCTION}

A group of lawyers met in a small, dusty railway town in cattle-country east of the Rocky Mountains in the spring of 1899. Their meeting established the Calgary Bar Association, reflecting their consensus, "that the Bar of Calgary were sufficiently numerous to form an association for the purpose of cultivating a feeling of professional brotherhood, discussing various matters affecting the interests of the profession, and taking united action thereon."1

The matters most urgently in need of collective action, they thought, were the development of a conveyancing tariff, agreement on uniform office hours, and confronting the problem of "unlicensed conveyancers." From some viewpoints, the lawyers' projects discussed in this article seem to provide inauspicious origins for organized professionalism, even in the cowboy capital of the British Empire. Whereas professional rhetoric makes much of public service sometimes elevating professional self-governance to the status of an entrenched constitutional "right" - the nitty-gritty of professional organization seems to have been self-interest. Their specific objectives were classic trades-union stuff: money, work-week, and monopoly. From one viewpoint, this hints of professional conspiracy against clients, community, and state.

Alluring though it may be, such interpretations dreadfully caricature processes of professionalization. I wish to interrogate the history of the "professionalization" of Canadian lawyers in order to develop broader understandings of professionalism and lawyers alike. There is more here than meets the eye.

\section{The Novelty of LAWYers' Professionalism}

Lawyers west of Ontario spearheaded the movement that created modern professional forms in Canada. Although historical antecedents of some sort exist for every "innovation," this is almost entirely a twentieth-century story. The forms and cultures of the professionalism we experience did not exist anywhere before the twentieth century. ${ }^{3}$ The high-water mark of European imperialism, the spatial extension of both the United States and the Canadian Dominion, and the creation of modern professional structures occurred simultaneously. Each process affected the others.

In its paradigmatic expression, professionalism incorporates demanding admission standards, mandatory and extended formal education, examinations, admissions screening, state licensing, prohibitions on "unauthorized" practice, self-regulation, written "codes" of conduct, and technocratic or meritocratic culture. In its peculiar combinations and in its relationship to a culture that was being consumed by "galloping hegemony of instrumental reason," all this

Minute Book of the Calgary Bar Association (12 May 1899) [archived at the Glenbow-Alberta Institute]. I have reviewed such arguments in W. Wesley Pue, "In Pursuit of Better Myth: Lawyers' Histories and Histories of Lawyers" (1995) 33 Alta. L. Rev. 730 [Pue, "Better Myth"].

I do not wish to be taken as making the nonsense argument that "professionalism" or "professions" did not exist in earlier times, but rather that twentieth-century Canadian professionalism is distinctive in its forms, manifestations, and cultures. Earlier forms of professionalism are also to be treated seriously in their own right: see Wilfrid R. Prest, ed., The Professions in Early Modern England (London: Croom Helm, 1987). 
is very much part of larger twentieth-century phenomenon. ${ }^{4}$ The whole, distinctly greater than the sum of its parts, combined in our grandparents' and great-grandparents' generations to form the core "structures" or forms of contemporary professionalism. ${ }^{5}$ North American professionalism was a new social technology for new times.

Noting this suggests the importance of several oft-overlooked themes. Most obviously, the novelty of contemporary professional form deserves greater emphasis than it is generally accorded. This is particularly so in the case of the legal profession. Because "law" is obviously an "ancient" profession, the suggestion that some essence of the existing profession might be of recent origin strikes many as very nearly heretical. Understandings of lawyers' professionalism in Canada and in other "British Diaspora" lands (including the U.S.) characteristically assume that, although much changes in professional culture, the essential forms or structures have a timeless quality about them. The distilled "essence" of professionalism - corporate structures, codes of ethics, effective "self-regulation," rigorous training programs, and admissions standards - are often assumed to have existed since time immemorial, only relatively inconsequential matters of "detail" changing over the generations. Not infrequently, key features are traced back through presumed genealogies to mysterious origins at the English Inns of Court in a time before recorded professional history. A heavy overlay of myth needs to be peeled back if the cultural origin of professionalism in our age is to be understood. ${ }^{6}$

\section{Structures and Cultures of Legal Professionalism}

The second theme is more complex. Broadly, it is that professional forms themselves need to be understood as cultural artifacts, that "culture" and "structure" are properly understood as mutually constitutive, not as distinct forces. There is no "base," no bedrock professional core that is unmoved by the currents of time. The case study of Canadian legal professionalism adds support to the "general theoretical argument that conceptual distinctions between structure and

4 Charles Taylor, The Malaise of Modernity (Concord, Ont.: Anansi Press, 1991) at 112 (and on the nature of instrumental reason, see 5-6). Cf. the tracings-out of professionalism provided by Harold Perkin, The Rise of Professional Society: England since 1880 (London: Routledge, 1989); James C. Foster, The Ideology of Apolitical Politics: Elite Lawyers' Response to the Legitimation Crisis of American Capitalism, 1870-1920 (New York: Garland, 1990); Jerold S. Auerbach, Unequal Justice: Lawyers and Social Change in Modern America (New York: Oxford University Press, 1976); Andrew Abbott, The System of Professions: An Essay on the Division of Expert Labor (Chicago: University of Chicago Press, 1988). Cf. Dorothy Ross, The Origins of American Social Science (New York: Cambridge University Press, 1990); John McLaren \& Hamar Foster "Hard Choices and Sharp Edges: the Legal History of British Columbia and the Yukon" in Hamar Foster \& John McLaren, eds., Essays in the History of Canadian Law, Vol. VI: British Columbia and the Yukon (Toronto: University of Toronto Press, 1995) 3.

I invoke this convenient and commonsensical understanding of professional "structures" in order to avoid the necessity of taking on the full-blown debate as to what, precisely, constitutes "structure" in social analysis. My work-a-day approach to professional structures in the twentieth century seems to fit William H. Sewell's definition that "[s]ets of schemas and resources may properly be said to constitute structures only when they mutually imply and sustain each other over time": William H. Sewell, Jr., "A Theory of Structure: Duality, Agency, and Transformation" (1992) 98 American Journal of Sociology 1 at 13 .

$6 \quad$ See Pue, "Better Myth," supra note 2; Sewell, ibid., addresses the ways in which actors often falsely invoke history in order to effect transformation. See also Eric Hobsbawm \& Terence Ranger, eds., The Invention of Tradition (Cambridge: Cambridge University Press, 1983). 
culture have lost force and utility in providing compelling theoretical maps, accounts, and images of the social world."

A cultural revolution of sorts transformed the structures of legal professionalism in the British Empire between 1867 and the Second World War. This was spurred, most dramatically, from Prairie Canada. The lawyers who led these efforts imagined that, by getting the structures of legal professionalism "just right," they would transform the country as a whole. Once their goals of structural transformation were attained, however, the larger cultural project they championed fell into disfavour. Less perceptible, lacking dramatic moment, subsequent changes were real nonetheless. The forms they created survived, but all meaning attributed to them was turned upside down by subsequent generations.

This article identifies changes in the first third of the twentieth century, illustrating how professional forms emerged from the cultural predispositions of reforming lawyers. Though subsequent metasomic processes cannot be explored here, they need to be noted so as to avoid leaving a misleading impression of the effects of the transformations described in this article. Often operating in directions opposite to those intended by the cultural revolutionaries of the earlier decades, a narrow and constrained technocratic pragmatism supplanted the essentially moral vision of modern professionalism's founding fathers.

\section{DOMINION AND EMPIRE}

Before considering professional transformations in detail, it is useful to pause briefly to consider the social contexts from which they emerged. The bursts of Canadian professional reform between 1910 and 1939 occurred in heady times. For a brief period, Canadians fantasized that the world was theirs to lead and believed in turn that Canada's future lay in the west: "Calculations of prairie greatness and celebrations of imperial power inevitably ran together; the west would have a population of 100 million; it would be the bread-basket of the world; it would become the centre of gravity for all Canada; and, if it ruled Canada, and Canada led the empire (as it soon would), then, as anyone could see, the west would lead the world." Not surprisingly, many reform initiatives originated in the Canadian west and especially in the prairie provinces (Manitoba, Saskatchewan, and Alberta). The west was then an important place, simultaneously the object and the soul of Canadian imperialism. Conditions were ripe for social experimentation.

Numerically small and finding themselves in a "new" land, prairie legal professions lacked the inherited social capital enjoyed by lawyers in Ontario and the east. They faced special difficulties in attempting either to assert cultural leadership or to establish its condition precedent, a secure market niche. The political communities of the prairies were hostile to privilege, infused with an egalitarian and reform ethos. Even the structures of government itself could not be taken for granted. The mood was riotously democratic, consistent both in its rejection of hierarchy, and in its questioning of the authoritative voice. At the same time, 
extraordinarily rapid social change was under way. Outside forces perpetually destabilized the region economically, socially, and politically. The effects of a newly industrializing continent's "distended society"9 were powerfully felt. Successive waves of populist politics threatened status, wealth, privilege, hierarchy, and order.

The region participated in a reforming culture shared with other parts of Anglo-Canada, ${ }^{10}$ but it was less inhibited by the constraint of convention or the gravitational pull of congealed hierarchies. In Canada's "new" lands, relatively greater emphasis was placed on freedom and its prerequisite, the governance of the good and the deserving. Amongst the Anglo-elite, frontier egalitarianism combined creatively with pride in "Britishness," and a belief in pioneer virtue. They held out the hope that this new land "could re-create the individual just as it improved upon the social order." A "militant view of British civilization" emerged and "the goal of prairie social leaders - a Protestant, law-respecting, English-speaking community in which democracy and social equality were fundamental assumptions - seemed within reach."12 Proud of their Britishness, western leaders were nonetheless "not complacent about British social achievements" and they insisted on their "freedom to improve upon the parent culture."13

Yet, the first three decades of the twentieth century brought unusual challenges. The newness and social fluidity which promised so much also appeared in threatening guise. The Dominion seemed to totter on a knife-edge between heaven on earth and a hell of human making. Massive urbanization, industrialization, recession, war, and growing xenophobia all took their toll. Economic dislocations corroded confidence in the future of governance. Class, ethnic, and rural-urban divisions were accentuated, culminating in a post-war burst of radicalism more pervasive than any other in North America. Winnipeg's crippling General Strike of 1919 was stunningly effective. ${ }^{14}$ Anglo-elites experienced a rapid, discomforting erosion of confidence in their ability to assimilate newly "dangerous" others into proper British ways. Buffeted by temperance, women's suffrage, social gospel, labour radicalism,

Robert H. Wiebe, The Search for Order, 1877-1920 (New York: Hill and Wang, 1967) at 39.

Mariana Valverde, The Age of Light, Soap, and Water: Moral Reform in English Canada, 1885-1925 (Toronto: McClelland \& Stewart, 1991); Carl Berger, The Sense of Power: Studies in the Ideas of Canadian Imperialism, 1867-1914 (Toronto: University of Toronto Press, 1970); Ramsay Cook, The Regenerators: Social Criticism in Late Victorian English Canada (Toronto: University of Toronto Press, 1985).

Friesen, supra note 8 at 304, discussing the novels of Ralph Connor.

Ibid. at $342-43$.

Ibid. at 342 .

Ibid. at 358,361 . The strike, which seemed to substitute government by "strike committee" for the ordinary organs of municipal government from 15 May to 21 June 1919, registered powerfully on elite consciousness. The establishment of a "proletarian dictatorship" was explicitly threatened. For a useful review of existing historiography and of previously unexplored archival records relating to the Winnipeg General Strike, see Ken Kehler \& Alvin Esau, Famous Manitoba Trials: The Winnipeg General Strike Trials - Research Resource (Winnipeg: Legal Research Institute of the University of Manitoba, 1990); Craig Heron, ed., The Workers' Revolt in Canada, 1917-1925 (Toronto: University Toronto Press, 1998); Tom Mitchell, “'To Reach the Leadership of This Revolutionary Movment': A.J. Andrews, the Canadian State and the Suppression of the Winnipeg General Strike" (1993) 18:2 Prairie Forum 239; Tom Mitchell, “'Repressive Measures': A.J. Andrews, the Committee of 1000 and the Campaign Against Radicalism After the Winnipeg General Strike" (1995-96) 3.2 \& 4.1 Left History 133. The United States experienced similar concerns which also motivated its "Bar Association Movement": see Foster, supra note 4 at $97 \mathrm{ff}$. 
progressivism, the farmer's and co-operative movements, socialism, and maternal feminism, regional consciousness threatened to disintegrate under the pull of centrifugal forces.

Knowing that lasting social peace could not grow from the barrel of a gun, elites faced the conundrum of how best to contain radical urges in a society where deeply-held commitment to an open, democratic, egalitarian social order co-existed with quite contrary cultural currents and with immense class and ethnic inequities. Lawyers kept all options under review as they contemplated their professional and civic futures. A degree of professional cohesion was attained through multiple professional and social connections, including those formed through the work of the Canadian Bar Association. Regional, Dominion-wide, and international webs of professional interconnection provided ideas, promoted consensus, and provided legitimation for novel professional projects.

Looking southward they discovered a social vision which held forth the promise of founding a better world on terrain mid-way between the Bolshevik abyss and a sort of Ancien Régime repression on the other. The middle ground was professionalism.

\section{Remaking Canadian Legal Professionalism}

During the first half of the twentieth century, Canada was divided into nine provinces (Newfoundland not yet having joined the Dominion) and extensive, sparsely populated, northern territories which were administered as colonies of the Dominion government. Quebec was - and remains - distinct from all the others, a civil law jurisdiction living in complex relationships to common law Canada. Its legal professions, cultures, and history are distinctive. Respecting that difference I make no attempt to fold Quebec into the larger Canadian whole. This article focuses on legal professions in the "rest of Canada."

Each of the eight common law provinces had its own structures of professional regulation, typically featuring a provincial "law society" or equivalent body established under provincial legislation. ${ }^{15}$ All solicitors and barristers were required to be members of the law society of their province. Although Canadian federalism precludes any possibility of a pan-provincial regulatory body, reform-minded lawyers of the early twentieth century developed a national voluntary association through which to promote their professional visions. The "Canadian Bar Association" (CBA), which emerged as an important force in 1914, was the creature of lawyers who had become frustrated in varying degree by the inaction of provincial law societies (the formal regulatory bodies). Formed quite deliberately within the realm of culture, part of its purpose was to spur those bodies into action. It was backed up or egged on by an array of local "bar associations," law student organizations, and similar voluntary bodies, organized with varying degrees of formality, ambition, and effectiveness. ${ }^{16}$ Although Canada was a self-

15 A consequence of the division of powers under the Canadian constitution.

16 The Vancouver Law Students Association was a particularly important locus of professionalizing activity. It and the Vancouver Bar Association played key roles in the development of British Columbia legal education. See W. Wesley Pue, Law School: The Story of Legal Education in British Columbia (Vancouver: University of British Columbia, Faculty of Law, 1995) [Pue, Law School]. For writings on other similar bodies, see William C.V. Johnson, ed., The First Century: Essays on the History of the County of Carleton Law Association by Various Hands on the Occasion of the Association's Centenary, 1888-1988 (Ottawa: Bonanza Press, 1988); Robert Crawford, "The New Westminster Bar Association, 
governing colony or "British Dominion," it did not follow the English model of a "divided profession." In each of the common law provinces, barristers and solicitors, though formally distinct, were members of a single professional body. Most lawyers were both "barrister and solicitor" (a usage which continues to the present) and, although some elite lawyers earnestly wished to create a distinctive and elite barristers' profession, ${ }^{17}$ this never came about.

The CBA (confusingly, never restricted to barristers) provided a focal point for new initiatives. Its influence was felt across Canada and the patterns of professionalism which emerged were strongly shaped by it. Canadian professional reformers spearheaded a fundamental reshaping of their common law structures of legal professionalism. Significant reforms were implemented with regard to qualification, education and admission, professional ethics, the regulatory powers of professional organizations, and the assertion of a lawyers' monopoly over "legal" services.

Taken together they radically reworked existing structures of professionalism to the point where something new and distinctive had emerged.

\section{QuAlification, EduCation, ANd AdMission}

The training, education, and socialization of aspiring lawyers was central to the reform agenda. During the early twentieth century, Canadian lawyers moved decisively away from their English inheritance. In the place of almost exclusive reliance upon apprenticeship they created ambitious blueprints for a new sort of legal education. The new model was explicitly cultural in content, university focused, rigorous, and taught in novel ways. New law schools emerged in Winnipeg, Regina, Saskatoon, Calgary, Edmonton, Victoria, and Vancouver (later consolidated in Winnipeg, Saskatoon, Edmonton, and Vancouver). Most were affiliated with the provincial university. Moreover, there were significant developments in curriculum, staffing, and program delivery at the older law schools in Fredericton, Halifax, Montreal (where McGill uncomfortably straddled the common law and civil law worlds), and Toronto. Early twentieth-century reformers sought to raise the pre-law educational requirements so that only university graduates would be admitted to legal education (a goal attained only in the late century).

The founders of twentieth-century Canadian legal education sought nothing less than to impose a uniform "cultural curriculum." Their objective involved more than merely producing better legal technicians. By restricting entry to the right persons and subjecting them to the right sort of legal education, they sought to achieve an enduring transformation of the law students' inner essence. They expected a new class of graduate lawyer to emerge: lawyers who were

1894-1994" (1994) The Advocate 221-226. The story of the Calgary Bar Association is to be found in its own minutes, archived at the Glenbow Archive, Calgary, and in 23 volumes of transcripts of oral history interviews pertaining to the legal history of southern Alberta circa 1900-1982. Professionalizing movements in Manitoba, Ontario, and British Columbia are discussed respectively in Dale Gibson \& Lee Gibson, Substantial Justice: Law and Lawyers in Manitoba, 1670-1970(Winnipeg: Peguis, 1972); Christopher Moore, The Law Society of Upper Canada and Ontario's Lawyers, 1797-1997 (Toronto: University of Toronto Press, 1997); Alfred Watts, Q.C., History of the Legal Profession in British Columbia, 1869-1984 (Vancouver: Law Society of British Columbia, 1984).

17 This was, for example, briefly considered within the Law Society of Manitoba during the 1920s. A short period of formal division was ended in Ontario in 1854: Moore, ibid. at 109. 
technically competent but also better people, permanently converted to a deep inner understanding of the virtues of British law. Inculcating the wisdom, judgment, and the ethics of gentlemen was the central goal. It was hoped that an army of gentlemen lawyers would emerge, to be dispersed over Canada's enormous and varied territory, carrying the life-blood of British civilization within them. Lawyers were to become missionaries in service of a secularized triune: law, Britishness, and civilization. ${ }^{18}$

\section{LAW SOCIETIES}

Reformers also sought to mutate existing provincial law societies into active agents of a new professionalism. They wished to do so in part to achieve particular instrumental goals. Symbolism was equally important however. Law societies that played an active role in the project of professionalism would enjoy enhanced prestige and enlarge the dignity of the profession as a whole. Lying below the field of vision of most twenty-first century observers, such symbolic objectives were viewed as considerable and distinct "goods" in and of themselves. The dignity of the profession and the prestige of its collective leadership were no small matters in an era when notions of honour, dignity, and gentlemanliness still carried considerable social freight.

In this respect the reform of law societies was nestled within a larger vision of social ordering. Reformers wished to implant forms of social governance which were neither narrowly economic nor exclusively "political." Law societies, like bar associations, gentlemen's clubs, and volunteer associations of all sorts were thought to occupy an important space in civil society. They were to secure their niche in a realm which was neither fully "public" nor fully "private," acting for the good of public and state alike - but distinctly not as "State" agents. A particular understanding of constitutional governance informed professional reform. ${ }^{19}$

This repositioning was most apparent with regard to revamped law society roles respecting ethics policing, admissions and qualification, discipline, and monopoly protection.

\section{LAW SOCIETIES' ROLES}

\section{A. Ethics Policing}

A radical remaking of approaches to policing the "ethics" of practising lawyers took place, the most tangible marker being the development of an ethics code. Undertaken at the initiative of the CBA this appears in retrospect to have been a logical, perhaps necessary, development

18 See W. Wesley Pue, "British Masculinities, Canadian Lawyers: Canadian Legal Education, 1900-1930" in Robert McQueen \& W. Wesley Pue, eds., Misplaced Traditions: The Legal Profession and the British Empire (Annondale, Austl.: Federation Press, 1999), which originally appeared as a special issue: (1999) 16 Law in Context 80 [Pue, "British Masculinities"].

19 The connections between professional organization and constitutional structures of governance in society at large are sketched out in Terence C. Halliday \& Lucien Karpik, "Politics Matter: A Comparative Theory of Lawyers in the Making of Political Liberalism" [Halliday \& Karpik, "Politics Matter"] in Terence C. Halliday \& Lucien Karpik, eds., Lawyers and the Rise of Western Political Liberalism: Europe and North America from the Eighteenth to Twentieth Centuries (New York: Oxford University Press, 1997) 15 [Halliday \& Karpik, Rise of Western Political Liberalism]. 
of modest proportions. In fact, however, the move was highly controversial at the time. It marked a striking deviation from British models of lawyers professionalism. ${ }^{20}$

The CBA's cultural authority was powerfully felt and most provincial law societies soon embraced the notion that a formal promulgation of professional ethical standards was desirable. They in their turn sought changes in their statutory powers so as to expand their disciplinary reach into new territory. The content of Canada's first code of lawyerly ethics has provoked insightful scholarly commentary focused on its coverage, gaps, and omissions, ${ }^{21}$ but for present purposes it is the novelty of this form of "ethical" regulation rather than its particulars which most bears noting.

\section{B. ADMISSION AND EDUCATION}

In and of themselves, the development of more formalized legal education for some aspiring lawyers (mandatory formal education for all aspiring lawyers came much later) and the promulgation of hortatory ethical codes operate "only" in the realm of culture. The matter was not left there however. Further innovations gave force to the cultural aspirations of elite lawyers.

One area related to the "gatekeeping" function of law societies. Issues surrounding the eligibility of women for admission to the legal professions of Canada came to a head in some jurisdictions. There were also statutory changes relating to the enrollment of "foreign," aboriginal, or foreign-qualified lawyers. Both types of initiative clearly involved responses to centrally important questions regarding just what sort of person from what sort of background could properly embody law in a new British Dominion, a question not yet adequately explored in Canadian historical writing. ${ }^{22}$

An earlier attempt to create a code had been turned back in Ontario and the Canadian Bar Association (CBA) initiative was strongly resisted by prominent Ontario judge William Renwick Riddell on a number of grounds involving professional tradition and principle. See W. Wesley Pue, "Becoming 'Ethical': Lawyers' Professional Ethics in Early Twentieth Century Canada" (1991) 20 Man. L.J. 227 [Pue, "Becoming Ethical"], also published in Dale Gibson \& W. Wesley Pue, eds., Glimpses of Canadian Legal History (Winnipeg: Legal Research Institute of the University of Manitoba, 1991) 237. Jonnette Watson Hamilton, “Metaphors of Lawyers' Professionalism” (1995) 33 Alta. L. Rev. 833.

See, however, Mary Kinnear, In Subordination: Professional Women, 1870-1970 (Montreal: McGillQueen's University Press, 1995); Joan Brockman, "Exclusionary Tactics: The History of Women and Visible Minorities in the Legal Profession in British Columbia" in Foster \& McLaren, supra note 4 at 508; Carol A. Aylward, Canadian Critical Race Theory: Racism and the Law (Halifax: Fernwood, 1999) 44-45; Lois K. Yorke, "Mabel Penery French (1881-1955): A Life Re-Created" (1993) 42 U.N.B.L.J. 3; Constance Backhouse, Petticoats \& Prejudice: Women and Law in Nineteenth-Century Canada (Toronto: The Osgoode Society, 1991); Constance B. Backhouse, “"To Open the Way for Others of my Sex'; Clara Brett Martin's Career as Canada's First Woman Lawyer" (1985) 1 C.J.W.L. 1; Pue, Law School, supra note 16; Peter M. Sibenik, "Doorkeepers: Legal Education in the Territories and Alberta, 1885-1928" (1990) 13 Dal. L.J. 419; Watts, supra note 16; Dawna Tong "A History of Exclusion: The Treatment of Racial and Ethnic Minorities by the Law Society of British Columbia in Admissions to the Legal Profession" (1998) 56 The Advocate 197; Pue, "British Masculinities," supra note 18. Futher, Margaret Thornton, Dissonance and Distrust: Women in the Legal Profession (Melbourne: Oxford University Press, 1996) is, in part, an outstanding study of the embodiment of law in lawyers. The book is discussed in Sara Ramshaw \& W. Wesley Pue, "Feminism Unqualified: A Review of Margaret Thortonton's Dissonance and Distrust: Women in the Legal Profession" (1997) 15 Law in Context 166. Statutory changes included: An Act to Amend the Statute Law, S.S. 1912-13, c. 43 (amendment to s. 37 by adding new s. 37(a), allowing Benchers in their discretion to make rules providing for the admission 
Other changes expanded the ambit of discretion exercisable by the governing boards of law societies (Benchers) in making decisions about admissions and qualifications. In some cases statutory redefinitions of law society powers were passed (sometimes retroactively) in order to facilitate the creation of full-time professional law faculties. ${ }^{23}$

Such changes were important both in themselves and for their symbolic impact. The honour of the legal profession and hence its cultural authority was thought to be much bound up with its discretionary authority: the wider the discretion, the greater the honour, and hence, the greater the cultural capital of the profession. A high point in this movement (in one way of seeing things) was the judgment of Hunter C.J. in Re Hagel v. Law Society of British Columbia holding that there "is no right of admission" to the law society. ${ }^{24}$ Chief Justice Hunter explained that

the discretion to call or to admit ought to be left exclusively to the Benchers ... it would not be in the public interest to permit any right of review. It must be evident that a judge is not in as good a position to pass on a matter of this kind as the Benchers... There is a latitude and discretion in such a matter inherent in such a tribunal as the Benchers which is not available to a Court. ${ }^{25}$

The ratio decidendi (reasons for decision) of the Hagel case could have been narrowly expressed as limited to circumstances in which a fully qualified lawyer who just happens to have been imprisoned for three years for aiding a jail break by smuggling a gun and rope into one of his clients subsequently seeks admission to the legal profession in another province. ${ }^{26}$ Chief Justice Hunter, however, sought to establish the broadest possible scope of cultural authority for the Benchers. In so doing he imagined himself to be according the colonial law society a gentlemanly status and a role equivalent to that of England's ancient Inns of Court. ${ }^{27}$ Similar cultural presuppositions also underlay the British Columbia courts' decisions in the late 1940s upholding the Law Society's rejection of a communist who, political belief apart, was

of women to practise as barristers and solicitors); An Act to amend "The Law Society Act", S.M. 1912, c. 32 (interpretation section, s. 2 amended adding that persons includes females within the Act); The Legal Profession Act; An Act to amend the Statute Law, S.A. 1911-12, c. 4, s. 29(2) (modest changes to provisions for enrollment of British, colonial, or foreign legal practitioners; s. 29(3) (change to the oath sworn and provisions for custody of roll of society).

See e.g. An Act to amend "The Law Society Act", S.M. 1909, c. 29, s. 54(d) (the admittance of attorneys not practising in the province rendered subject to rules framed by the Benchers); An Act to amend "The Law Society Act", S.M. 1911, c. 23 (increasing discretion of Benchers regarding the admission of members and students-at-law in special cases); An Act to amend "The Law Society Act", S.M. 1915, c. 37, s. 40 (powers of Benchers to make rules for improvement of legal education amended by specifically including the establishment and maintenance of a law school, permitting regulations respecting attendance at classes or instructions at law, and so on); An Act to Amend the Motor Vehicle Act, the Unearned Increment Tax Act, and Certain Other Acts and Ordinances, S.A. 1921, c. 5 amended the Legal Profession Act (new provision s. 35 (s. 32 in 1922 amendments) providing for the admission of University of Alberta graduates having completed degree in law and served articles); An Act to Amend the Legal Profession Act, S.A. 1947, c. 70 (adding s. 62(a) permitting Benchers to make provision for enrollment of students from other universities than the University of Alberta under certain conditions). Some related developments are discussed in works such as Sibenik, supra note 22; Gibson \& Gibson, supra note 16; Watts, supra note 16; Moore, supra note 16. [1922] 31 B.C.R. 75 at 77 [Hagel].

Ibid.

See Gibson \& Gibson, supra note 16 at 211.

Hagel, supra note 24 at 76-77. 
fully qualified. The patterns of decision-making in Martin v. Law Society of British Columbia ${ }^{28}$ have conventionally been understood as manifesting a sort of hysteria-driven conspiracy of the legal elite. That interpretive frame, rendered plausible by the subsequent McCarthyite purges in the U.S. and by the fact that the judges undoubtedly shared the Benchers' opinion that communism was a 'pernicious creed,' obscures other aspects of the case. The Benchers' genuine commitment to an ideal of lawyering as a gentlemanly service and to visions of professional governance which were thought to advance this were shared with the judiciary. The assertion that "it is not for the Court to substitute its view for that of the Benchers" ${ }^{29}$ (expressed by Coady J. at the Supreme Court of British Columbia, and endorsed by the Court of Appeal) simultaneously reflects a constitutional commitment of sorts within "administrative law" and an understanding of the roles of Canadian legal professions which would have been unintelligible before the reforms spearheaded by the early CBA. ${ }^{30}$

\section{Discipline}

The historical antecedents of the contemporary legal professions' disciplinary powers over its members is easily misunderstood. Most post-World War II observers tend to assume that such powers are somehow inherent in the idea of legal professionalism (they are not). Hence it is commonly assumed that such bodies have always (or practically always) had full, unfettered, discretion to discipline lawyers by means of censure, suspension, or expulsion. It also seems logical, from our vantage point, to assume that the power to expel a member necessarily has the consequence that that person is thereafter prohibited from earning a living from the practice of law. We take for granted the effective policing of a monopoly on legal services. ${ }^{31}$ Such assumptions, each of them false, are frequently reflected in hurriedly-produced professional apologetics but also underlie some of the more reflective writing on professional history. ${ }^{32}$

At least three further factors contribute to confusion. First, the waters are muddied by a rather unreflective North American elision of the histories of the barristers' and solicitors' professions. ${ }^{33}$ Second, confusion arises when the historic roles of courts and of lawyers' organizations are misunderstood. The inherent right of superior courts to limit who can appear before them and how those people (whether solicitors/attorneys or advocates) may conduct themselves has long been recognized. It should never be mistaken for the exercise of

Re Legal Professions Act; Re Martin, [1949] 1 D.L.R. 105; Re Legal Professions Act, Re Martin, [1949] 2 D.L.R. 559 (B.C.S.C.); Martin v. Law Society of British Columbia, [1950] 3 D.L.R. 173 (B.C.C.A.) [Martin].

30 Supra note 28.

31 Note however the recent case of Maurice Sychuk, disbarred by the Law Society of Alberta for murdering his wife, and denied reinstatement at the conclusion of his sentence: Law Society of Alberta v. Sychuk, [1999] L.S.D.D. No. 15 (QL).The press reported that Mr. Sychuk nonetheless earned a living from working in Calgary in the field of "oil and gas," an area within his established legal expertise. $C f$. Fred Edge, The Iron Rose: The Extraordinary Life of Charlotte Ross, M.D. (Winnipeg: University of Manitoba Press, 1992), providing an account of a woman physician who was able to practise medicine despite being refused recognition by formal regulatory bodies.

32 One among many misperceptions of the histories of legal professions found in professional apologetics. See Pue, "Better Myth," supra note 2. 
disciplinary powers by an organized professional body. These are quite distinct matters. ${ }^{34}$ Finally, and most confusingly, the organized legal professions' long-standing exercise of power to expel convicted criminals is all too easily mistaken for a plenary disciplinary power. Though the former is of relatively ancient vintage within the Anglo-Canadian tradition, the latter has only been asserted in relatively recent times. ${ }^{35}$

Curiously, the writings of Justice William Renwick Riddell have added to the confusion. A prominent figure in the early twentieth-century legal profession, Riddell J. was both a Canadian legal historian and a student of legal professionalism. ${ }^{36}$ His conclusion that Ontario's Law Society (Law Society of Upper Canada) had enjoyed full disciplinary powers over members of the bar, attorneys, solicitors, and articled clerks since 1876 (or 1881 ) $^{37}$ is easily misconstrued as having more expansive meaning than intended. It stands in apparent self-contradiction to his forceful argument against the adoption of codes of professional "ethics" by Canadian law societies. On that matter he argued vigorously that "[i]f it were proposed to make the Code a Penal Code violation of which would render the offender liable to disbarment, legislation would be necessary, and many considerations would arise ... which to my mind would be fatal to the proposition." 38

The apparently glaring inconsistency is easily resolved when it is recalled that when one wrote in 1926 of a law society having "full disciplinary powers," this in no way implied a plenary and exclusive jurisdiction over lawyers' conduct of the sort we now take for granted. Though the idea that law societies should be entirely sufficient and efficient in the control of their members' conduct was "in the air" in the early twentieth century, no such plans had yet come to fruition. Existing powers were constrained by quasi-constitutional understandings regarding the autonomy of individual lawyers, by the jealousy of the courts in preserving their

This aspect, which raises a question of professional discipline in the context of a constitutional separation-of-powers is ably dealt with in James Willard Hurst, The Growth of American Law: The Law Makers (Boston: Little Brown, 1950) at 278-79. The relationship between courts and professional bodies in the U.S. is complex and leads to some confusion between these quite different exercises of power. These matters are ably dealt with in William H. Hurlburt, The Self-Regulation of the Legal Profession in Canada and in England and Wales (Calgary; Edmonton: Law Society of Alberta; Alberta Law Reform Institute, 2000).

35 Robert Baldwin's fascinating report on the Law Society of Upper Canada's (LSUC) disciplinary powers, Law Society of Upper Canada, Minutes of Convocation, vol. 1:476, Report of the Committee on James Doyle (29 June 1833), prepared in relation to the case of James Doyle, who had been removed from the Court of King's Bench list of attorneys for misconduct, merits further scrutiny. See Moore, supra note 16 at 70 . Note however that in this case the primacy of the courts as the locus of discipline is taken entirely for granted. [archived at LSUC] text from an Exhibition prepared by the LSUC with financial support from the Law Foundation of Ontario.

37 William Renwick Riddell, The Bar and Courts of the Province of Upper Canada, or Ontario (Toronto: Macmillan, 1928) at 111-12. The legislative changes which Riddell addresses are ably explained in Curtis Cole, "A Learned and Honorable Body": The Professionalization of the Ontario Bar, 1867-1929 (Ph.D. Thesis, University of Western Ontario, 1987) [unpublished], c. 5, entitled, "To Purge the profession of those who bring disgrace upon their Brethern': The Bar's Assumption of Autonomous Professional Self-Discipline." See also Moore, supra note 16 at 149: "Discipline in the legal profession was also transformed. Though barristers had been disbarred for ungentlemanly behaviour as early as 1820 , only in 1876 had the society's disciplinary power been made explicit in the Law Society Act, and judges had continued to assert a right to discipline the solicitors enrolled by their courts." William Renwick Riddell, “A Code of Legal Ethics” (1919) 4 Reports of the Can. Bar Assn. 136 at 139. 
traditional authority over the legal profession, and by the terms of legislation in various provinces.

The idea that the organized legal professions should be the sole locus of disciplinary power over lawyers was in fact boldly innovative. So too the related notion that powers of discipline and punishment should be enforced in a field as nebulous as professional "ethics." 39 The hidden hand of the CBA was felt as a series of statutory changes transformed Canadian legal professions. The direction of movement was from rather loose gentlemanly guilds into something closer to the modern disciplinary apparatus we now take for granted. These changes gave clearer definition to law society powers over discipline, regularized or streamlined procedures, increased the ambit of that authority, and - over time - moved the supervisory jurisdiction of the courts further and further into the background. But none of this was part of any ancient English heritage. It was only in the first half of the last century that law societies were actively transformed into organizations with public regulatory roles which far surpassed those of earlier guild structures. ${ }^{40}$

Importantly, as their powers increased, so too did their "dignity." This mattered immensely to a generation less obsessed than our own with the efficacy of power and less exclusively focused on narrowly, pragmatically conceived instrumentalism.

\section{ASSERTing MonOpoly}

The final element of early twentieth-century transformations in Canadian legal professions was the extension of a lawyers' monopoly beyond its traditional domain (rights of audience or agency before superior courts) and increased protection within the widening "competition-free" zone. The protected zone expanded consistently during the second and third decade of the twentieth century. Saskatchewan, for example, made it unlawful to act under false pretenses

Riddell's objections were cogent. See Pue, "Becoming Ethical," supra note 20. Peter M. Sibenik's research has traced out developments in relation to professional discipline in Alberta. See Peter M. Sibenik, “The Black Sheep': The Disciplining of Territorial and Alberta Lawyers, 1885-1928” (1988) 3 C.J.L.S. 109 [Sibenik, "Black Sheep"].

40 This shift was reflected in a series of legislative changes to the framework of regulation by law societies including: An Act to Amend the Legal Profession Act, S.A. 1911-12, c. 4, s. 29; An Act to Amend "The Law Society Act", S.M. 1915, c. 37; An Act to Amend the Legal Profession Act, S.S. 1919-20, c. 44; An Act to Amend the Legal Profession Act, S.S. 1923, c. 49 [An Act to Amend the Legal Profession Act (Sask. 1923)]; An Act to Amend the Legal Profession Act, S.A. 1924, c. 19; An Act to Amend the Legal Profession Act, S.A. 1925, c. 13; An Act to Amend the Legal Profession Act, S.A. 1926, c. 18; An Act to Amend "The Law Society Act", S.M. 1926, c. 26; An Act to Amend the Legal Profession Act, S.A. 1928, c. 19; An Act to Amend the Legal Profession Act, S.S. 1933, c. 54 [An Act to Amend the Legal Profession Act (Sask. 1933)]; An Act to Amend the Legal Profession Act, S.S. 1936, c. 85; An Act to Amend The Legal Profession Act, S.M. 1943, c. 29 [An Act to Amend the Legal Profession Act (Man. 1943)]. Generally these provisions extended the powers of the Benchers to regulate the conduct of lawyers, limiting the authority of the courts in these matters. For accounts of law society disciplinary powers, see Watts, supra note 16, c. 10 at 117-32; Lee Gibson, "A Brief History of the Law Society of Manitoba" in Cameron Harvey, ed., The Law Society of Manitoba, 1877-1977 (Winnipeg: Peguis, 1977) 28 at 50; Gibson \& Gibson, supra note 16 at 128, 171-72, 240, 252, 257, 267, 305; Moore, supra note 16 at 61, 70, 125-26, 149-51, 300-302, 323-24, 326-29; Sibenik, "The Black Sheep," ibid., especially, "The Locus of Disciplinary Power" at 113-20; Cole, supra note 37 (pointing out that the courts' exercise of disciplinary jurisdiction concurrent with that of the law society in Ontario continued well into the twentieth century). 
by holding oneself "out to be a barrister and solicitor" whether or not the individual did so in appearing before the Court of Kings' Bench (1923). Manitoba extended lawyers' monopoly, first prohibiting unqualified individuals from threatening legal procedures or using documents simulating court forms (1932) and then protecting lawyers' monopolies over conveyancing (1933). Similar provisions were enacted in Alberta in 1936. In neighbouring Saskatchewan, non-lawyers were prohibited from threatening legal proceedings on behalf of a creditor (1933). In that province, the policing of monopoly by means of annual certification was strengthened in 1936. Manitoba again reinforced its unauthorized practice prohibitions in $1943 .^{41}$

Beneath the surface of legislative change, law societies invested considerable effort in enforcing prohibitions on "unauthorized practice." 42 Future research may reveal that this hidden terrain was where "the action" was.

\section{Remaking the Legal Profession: Summary}

All told then, the contours of professionalism shifted significantly, even if we restrict our gaze to the most formal level. Less visible transformations were advanced by means of the delegated rule-making authority and less formal policies of law societies and, in part, through the creative interaction of all aspects of lawyering with wider social, cultural, and intellectual contexts. $^{43}$

The more important questions, perhaps, are why these changes? Why in this place? Why at this time? We are taken part way to an answer by noting that this professional renewal was carefully planned in advance. Structural innovation, even in relatively narrow fields takes time,

An Act to Amend the Legal Profession Act (Sask. 1923), ibid., s. 37(1); An Act to Amend the Law Society Act, S.M. 1932, c. 22, s. 53; An Act to Amend The Law Society Act, S.M. 1933, c. 20, s. 53A; Act to Amend The Law Society Act, S.M. 1937, c. 26 (added 53(a), specified that the prohibition extended to corporations as well as to natural persons. Fines were imposed on unauthorized individuals preparing instruments for conveyancing of real and personal property); An Act to Amend the Legal Profession Act, S.A. 1936, c. 14, s. 59, am. by 59(a), imposing penalties for preparation of instruments (for reward) in relation to any real or personal estate or incorporation of joint stock proceedings; An Act to Amend The Legal Profession Act (Sask. 1933), ibid. (amending s. 64 of the Legal Profession Act; An Act to Amend the Legal Profession Act (Sask. 1936), ibid., enacting "[n]o person except those enrolled as barristers and solicitors of Saskatchewan and holding subsisting annual certificates issued to them pursuant to the rules and bylaws of the society shall practise at the bar of any court of civil or criminal jurisdiction in Saskatchewan..." and making it an offence for anyone without a subsisting annual certificate to willfully pretend to be qualified to act as a barrister or solicitor; An Act to Amend The Law Society Act (Man. 1943), ibid., ss. 53 and 54 repealed and replaced by a new, wider, s. 53, expressly including the drawing of wills within the lawyers' monopoly, prohibiting simulating court procedures, and prohibiting employment of disbarred persons. The new legislation allowed for injunctions to be obtained against unauthorized persons. Statutory exceptions to the ambit of unauthorized practice prohibitions protected public officers, notaries, and persons acting for themselves. On similar developments in British Columbia during this time period, see Watts, supra note 16 at 119-20.

This is revealed in the records of the Law Society of Manitoba. See also Watts, ibid. at 120; Peter M. Sibenik, The Doorkeepers: The Governance of Territorial and Alberta Lawyers, 1885-1928 (M.A. Thesis, University of Calgary, 1984) at 170-80, entitled "The Protective Impulse."

43 The full cultural import of legal education, for example, cannot be discerned from statutory histories alone but needs to be understood in relation to universities, curriculum, and wider cultural contexts. See Pue, "British Masculinities," supra note 18 and sources cited therein. Further evidence of the sorts of changes which might be involved at this "hidden" level are documented in P.J. Giffen, "Social control and professional self-government: a study of the legal profession in Canada" in S.D. Clark, Urbanism and the Changing Canadian Society (Toronto: University of Toronto Press, 1961) 117. 
labour, and energy. These are not tasks to be undertaken lightly, even where strong leaders find developed blueprints of change readily available for appropriation. Nor is it "rational" for individuals to undertake such projects - at least if rational behaviour is understood in terms of narrow self-interest. The time and energy demands are far in excess of any conceivable benefit individuals might derive from successful completion of such tasks. If we are to appreciate why leading lawyers invested so heavily in reforming their profession it is necessary to look outward to their beliefs and to their larger social contexts. The founders of Canada's modern legal professions believed that developing a certain kind of lawyers' hegemony was essential to the preservation of constitutional monarchy, liberal governance, and Britishness. It is their deep and public-spirited commitment to these ideals which explains their actions. Professionalization was part of larger projects aimed at securing a safe future for all they held dear. Their parochial work in transforming their own profession was part of their contributions to a much larger cultural revolution.

The context from which these changes emerged is well behind us, the culture of moral reform which spawned them invites ridicule. Nonetheless, their professional structures endure. This is so even though subsequent social changes have very nearly inverted the cultural ethos which originally gave them meaning. Subsequent processes have indeed transformed professionalism but have done so within inherited frames which sit oddly out of time in the twenty-first century.

\section{Canada: AN "American" Nation}

Canada is an "American" nation. ${ }^{44}$ Despite the then widespread affection for the British Empire, the dominant cultural influence on Canadian lawyers in this period arguably came from the United States of America. Long puzzled by the mystery of social order, North American social thought conceived of professionalism as the only acceptable bulwark capable of protecting ordered society from descent into "lawlessness and anarchy." 45 Never fully implemented in the U.S., a neatly packaged ideology of legal professionalism was available there. It came in a form which simultaneously advanced the cause of professional reform and deflected criticism, hostility, and anti-lawyer sentiment.

On both sides of the border an intensely moral professionalism developed, designed to advance the rule of the "righteous" and the rule of law rather than the government of either the masses or of those who were merely knowledgeable. Lawyers commonly thought of their profession in such terms. Justice O'Halloran of the British Columbia Court of Appeal, for example, gave voice to such a view:

Moreover, the law student's training is not manual training, but is training of the mind, not only in law, but if he wishes to be something more than a mere legal mechanic, he must study logic, history, in particular constitutional history, political science and economics, a certain amount of philosophy and acquire a reasonable familiarity with English literature, and know something at least of the literature of other countries. 
The job of a lawyer is basically to advise people upon all manner of things arising out of the complexities of life and the frailties of human nature. As such he cannot fail in time to acquire an influence upon others, impossible to reduce to purely material terms. It is not too much to say that the training and experience a lawyer undergoes fits him for leadership to a greater or less degree. Obviously such men should not be partial to political philosophies and movements that conflict with the interests of their own country.

By reason of these things, all countries throughout the ages have given the lawyer a correspondingly high place in society - particularly so in the case of the lawyer who pleads in the higher Courts. The object of law training is to attract young men of high character, and to train them in a manner that they will be trustworthy, honourable and competent in the performance of their legal duties, and will use such influence as they may have to maintain and improve but not destroy our Canadian constitutional democracy. They are to be the defenders and not the destroyers of liberty. They are expected to be sufficiently well-informed and experienced to distinguish between liberty and licence. ${ }^{46}$

It mattered deeply, in other words, that lawyers be gentlemen, right-thinking, and politically sound. Such understandings provided a pervasive common language which gave direction to developing legal professionalism and rendered the projects of professional elites palatable even attractive - to a wider public.

In developing a "moral" vision of professionalism, Canadians looked south for inspiration rather than "home" to Britain. They did so for several reasons. Proximity as well as ease and density of social contact account for much. So too does social fit. The U.S., like Canada, had suffered the disruptions associated with immigration, internal colonization, and the industrialization of an immense federation. It also was avowedly democratic, heterogeneous in ethnicity, language, and religion, regionally diverse, and heavily marked by a migrating frontier of European settlement. The U.S. experienced continuous change and was racked with uncertainty, at times overwhelmed by the sense of "the irrationality of life." ${ }^{\text {"47 }}$ By the turn of the century it had become a "distended" society marked by business and political disorganization, a widening "cultural gap between city and countryside," "[i]rresponsibility," and "ethical evasions." 48 "Respectable" citizens feared that "the true and simple America [was] in jeopardy from foes of extraordinary, raw strength - huge, devouring monopolies, swarms of sexually potent immigrants, and the like. ${ }^{, 49}$ If Britain represented Canada's origins, it was easy to imagine the U.S. as foreshadowing its future.

Seeking ordered freedom, "science" stepped in to fill the governmental void left by the overthrow of traditional sources of authority ${ }^{50}$ A novel political and cultural project emerged, a "culture of professionalism" in which lay persons were required to trust the integrity and omnicompetence of an emergent educated class: "Science as a source for professional authority

47 Burton J. Bledstein, Culture of Professionalism: The Middle Class and the Development of Higher Education in America (New York: Norton, 1976) at 322 (discussing the 1860s and 1870s). 
transcended the favoritism of politics, the corruption of personality, and the exclusiveness of partisanship." 51

The political corollary of all this was the rise of progressivism in its various mutations, the development of the bureaucratic state, "reform," an abandonment of party loyalties, and a search for mechanisms whereby authority in discrete areas of social life might be entrusted to "experts" for the good of all. ${ }^{52}$ Reformers of many stripes looked forward hopefully to a world made better by rational planning, education, proper procedures, regularity, and the creation of means by which to infuse "ethics" into the interstices of everyday life. ${ }^{53}$ Religion transmuted into "social gospel" and the notion that ethical life could be segmented was eroded. Regulation seemed desirable to generations who perceived change as fundamental, inevitable, and rapid, but who had not yet forgotten the moral claims of a "public sphere."

In this era, lawyers presented themselves as specialists in law but also as guardians of cultural knowledge, in effect, "universal experts." 55 "Professional" principles held forth the promise of containing social discontent and maintaining order. ${ }^{56}$ One formulation had it that "if the down-pull of government by plebiscite is to be arrested, if the vortex movement of democracy is to be counter-balanced, it will be accomplished mainly by the grace of the professional spirit." ${ }^{, 57}$ Curious admixtures of conservatism, reverence for property, social elitism, community spiritedness, laissez-faire, "service," and "duty" resulted.

\section{ObVious Unsuitability OF OTher Models}

Whatever the emotional tugs on colonial heartstrings, it was clear to all that English models of legal professionalism could not practicably be sustained in North America. The "fit" was difficult enough in Ontario and Atlantic Canada, impossible in Quebec and the west. Key elements of English legal professionalism could not be transplanted. A strong egalitarian ethos combined with the small numbers of lawyers in the west to make a rigid demarcation of solicitors from barristers impracticable - in sharp contradistinction to the experience of some

Ibid. at 90. Cf. Wiebe, supra note 9 at 161 . "Science" did not necessarily stand in opposition to religion in this period. For many, God, science, and cultural tradition for a time lived in mutually constitutive relations. See e.g. Cook, supra note 10. Nicholas Lemann, The Big Test: The Secret History of the American Meritocracy (New York: Farrar, Straus \& Giroux, 1999).

Cohen, supra note 45 at 107 :

Within two decades we have been whisked about and hurdled over Interstate Commerce Commissions, Public Service Commissions, Minimum Wage Laws, Industrial Boards, Workmen's Compensation Acts, Income Taxes, Inheritance Taxes... Truth is, the conservatives have turned progressives, the progressives have turned socialists, and the socialists are looking about for new wearing apparel. good effect in relation to the U.S. legal profession in Foster, supra note 4 at 12. 
other British "Dominions" and colonies. ${ }^{58}$ The legal professions in the western provinces were of recent origin, created by statute, and far removed in origin, structure, and governance from the English Inns of Court. Features central to the English barristers' profession were palpably absurd in the newest part of the New World at the dawn of "Canada's Century." Governance by a self perpetuating oligarchy, qualification on the basis of meals eaten, expected (but largely unenforced), conformity to imprecise principles of "etiquette," and regulation by itinerant dining clubs, to pick only the most obvious examples, could not be transplanted into a new place.

Ontario's Law Society, or its' younger cousin, the Law Society of England and Wales, provided models more suited to transplantation. U.S. models proved more compelling however. A significant trans-boundary intercourse took place amongst professional leaders. ${ }^{59}$

The evolving culture wove six strands of a new professionalism together. Not surprisingly, these bear striking resemblance to innovations actually implemented in common law Canada during the early twentieth century. The new model was founded on a confidence in professional meritocracy which in turn was to be constructed from stringent admission standards, formal education, examined expertise, and practical experience. It relied on an ongoing cleansing of the bar by means of the enforcement of ethical standards by professional governing bodies operating independently of state control. Minimum fee schedules and the creation of a secure monopoly over the right to provide legal services were seen as providing a necessary quid pro quo for such constraints on ordinary market principles and, of course, the suppression of all and any "unlicensed competitors" was necessary if the new structures were to be effective.

First taking shape as a coherent, deliberate, and workable "project" in the early twentiethcentury U.S., this web of professionalism had come to constitute a professional "common sense" by the time the CBA began to assert itself. ${ }^{60}$ The individual components, moreover, were understood as constituting a unitary structure, a "whole cloth" of inseparable strands. A compelling logic bound the whole together. It was thought, for example, that individuals would not be willing to pursue an extensive professional education unless certain privileges (the dignity attached to self governance) and financial benefits (mandatory fee schedules and protected monopoly) could be guaranteed. This in turn required statutory prohibition on unlicensed practice and the enforcement of codes of "ethics." Otherwise, the privileges could not be justified, the benefits could not flow. ${ }^{61}$ Because only practising lawyers could appreciate

58 Contrast, for example, the state of Victoria in Australia: Rob McQueen, "Together We Fall, Divided We Stand: The Victorian Legal Profession in Crisis 1890-1940" in W. Wesley Pue \& David Sugarman, eds., Lawyers and Vampires: Cultural Histories of Legal Professions (Portland, Or.: Hart, 2003) 293; J.R.S Forbes, The Divided Legal Profession in Australia: History, Rationalisation and Rationale (Sydney: Law Book, 1979).

59 Reports of proceedings for both the "American Bar Association" and the "Canadian Bar Association" during the early decades of the century reveal patterns of elite interaction which have yet to be properly assessed. For one example, see Sir James Aikins, "Inaugural Address of the President. Sir James Aikins, K.C., Knt., Lieutenant-Governor of Manitoba" (1918) 54 Can. L.J. 344 at 348 (discussing the immense U.S. influence on Canada) [Aikins, "Inaugural Address"]. Cf. Bernard J. Hibbitts, "“Our Arctic Brethren: Canadian Law and Lawyers as Portrayed in American Legal Periodicals, 1829-1911" in G. Blaine Baker \& Jim Phillips, eds., Essays in Canadian Law, Vol. VIII: In Honour of R.C.B. Risk (Toronto: University of Toronto Press, 1999) 241.

60 This is broadly the agenda set forth by Cohen, supra note 45.

61 See e.g. Cohen, ibid., c. XIV, entitled “"It Pays to Advertise.' Does It?” at 173. 
both the constitutional principles on which legality was based and the concrete problems which arose in day to day legal work, their own professional bodies, independent of state and lay interference alike, needed to be given charge of ethical and professional matters. ${ }^{62}$

Idealized "traditions" of the professional guild (emphasizing service orientation and anticommercialism) were melded with the new ideology of regulation, bureaucratic regularity, "scientific" credentialing, and ethical policing to produce a distinctly twentieth century, uniquely North American, version of professionalism. ${ }^{63}$ Julius Cohen's remarkable book, The Law: Business or Profession?, for example, is replete with self-conscious references to the ways in which a new "evolution of a new public opinion," American democracy's great gift to the world, ${ }^{\prime 65}$ mandated professional reforms. It called for nothing less than an entire new formulation of professionalism, emphasizing "duty," "service rather than profit," rigorous educational standards, professional conscience, and enforcement of ethical codes so as to "purge" the dishonorable from the profession. ${ }^{66}$ Of necessity, "unauthorized practice" would have to be prohibited and effectively punished. ${ }^{67}$

Canada's reform-minded lawyers too articulated a vision of professionalism as an immutable whole. This involved careful attention to defining the limits of acceptable society with an almost obsessive cultural emphasis on structured knowledge, rational education, and the virtues of science. ${ }^{68}$ Finally, they shared the widespread notion that professionalism provided a magic key capable of maintaining authority in a society rent by centrifugal forces.

The most articulate advocate of American-style professionalism in the period was the intensely proud British Canadian lawyer, Sir James Aikins. Variously a leading lawyer, Royal Commissioner, Manitoba Governor-General, and founding President of the CBA, Aikins

According to Cohen, ibid., at xvi, Dr. Felix Adler in 1908

presented to the public his conviction that the further solution of problems of ethics, in industry, in business, and in the professions, must come from the definite assistance of men who live with these problems; that it is not enough for our day and generation to have a general philosophy of ethics, but that there must be daily application of the philosopy to the fact, and that this can be best done by the experts in the line.

An English version of "professional society" arose at a similar time period. See Perkin, supra note 4. In its English manifestation, however, "professionalism" never attained the fully "modern" character of its North American mutation. See e.g. Richard L. Abel, The Legal Profession in England and Wales (New York: Blackwell, 1988); David Howard Laycock, Populism and Democratic Thought in the Canadian Prairies, 1910 to 1945 (Toronto: University of Toronto Press, 1990).

Cohen, supra note 45 at 144 . Cohen observes that "[u]nless we grasp the meaning of these changes in American thought, we shall pass by an understanding of the momentous changes taking place in the practice of the law" (at 143).

Ibid. at $127,143-44,151,155,158,159$.

See ibid. at 173-200, 277-78. Ideas of this sort were commonplace. See also "Unauthorised Practice of Law" (1919) 55 Can. L.J. 375, reproducing an article from Law Notes, (Northfield, U.S.). The article establishes linkages between questions relating to lawyers qualifications, ethical regulation, competition, bar organization, and the need to suppress competitors. Typical of the period, it amounts to a complete project of professionalization similar to that advanced in Cohen's work and implemented in Canada through the influence of the CBA.

See Laycock, supra note 63. On Canadian legal education, see Pue, "British Masculinities," supra note 18; W. Wesley Pue, “"The Disquisitions of Learned Judges': Making Manitoba Lawyers, 1885-1931" in Baker \& Phillips, supra note 59 at 512; W. Wesley Pue, "Common Law Legal Education in Canada's Age of Light, Soap and Water" (1995) 23 Man. L.J. 654. 
worked hard in the cause of professional reform. His address on the topic of "The Legal Profession in Relation to Ethics, Education and Emolument," delivered at the CBA meeting in Winnipeg in August 1919, makes clear the extent to which reforms of legal professionalism were implemented as part of an integrated plan. ${ }^{69}$ Like Cohen, his remarks point to the absolute imbrication of the political, economic, cultural and "professional" spheres.

Asserting that the lawyer's first duty is to the State, Aikins developed arguments against open admissions and in favour of both more rigorous educational requirements and more active "moral" policing:

It is a false notion of democracy that the right to practice law should be free for all, that anyone can practice it, and without serious loss to the public, operate or help to operate the expensive and intricate machinery of justice which the State creates for its safety and well-being. The administration of justice has always touched the nadir of its decline when the profession has been lowest in morals and least educated. In such times there is seen a tendency on the part of practitioners to regard the work of the Bar as a trade and not a profession, a thing to be bartered and not a national service to be sought after; then also is found the pettifogger, the ambulance chaser, the fabricator of evidence and the trickster, and the man who is alien to the professional spirit and its traditions, destitute of gentlemanly instincts, disrespectful to his seniors, and a slanderer of Judges. ${ }^{70}$

In tone and in content this echoes contemporary professional apologetics in the U.S. ${ }^{71}$ The Queen's Representative was remarkably “American” in his professionalizing role.

One central feature of this new vision was the articulation of a code of professional conduct coupled with a new determination on the part of professional governing bodies to actively seek out and expunge "undesirable" practitioners. This was thought necessary for professional cohesion, utility, and security. As Aikins said on another occasion, "[i]f the legal profession refuses to ruthlessly rid itself of its barnacles and fungus, how can the public be expected to extend to the profession, as a profession, the high honor, the dignity and revenue which that profession rightly deserves." ${ }^{172}$ This project of defining the good practitioner turned toward explicit class bias or nativism and wartime prohibitions on the admission of members of noncharter ethnic groups reflected a deep-seated fear of "foreigners." 73

Proceeding to develop the case in favour of a more thorough education of aspiring lawyers, Aikins acknowledged that this would require "adequate rewards for meritorious services" and

Sir James Aikins, "The Legal Profession in Relation to Ethics, Education and Emolument" (1919) 55 Can. L.J. 335 [Aikins, "Ethics, Education and Emolument"].

Ibid. at 335 [emphasis added].

Cf. e.g. Cohen's extended comparative "history" of professional admission standards and the cause of "justice" (Cohen, supra note 45).

"Vancouver Benchers" Vancouver Sun (13 December 1927) 8 (reporting on Aikins' view of the general reputation of the legal profession) [emphasis added].

See e.g. Aikins, "Inaugural Address," supra note 59, arguing that the experience of 1914-1918 demonstrated the desirability of careful immigration controls: "Even before the war that error was made manifest in industrial dissensions, in the ignorant, too often corrupt, use of the franchise and failure to understand the privileges and responsibilities of our free institutions.... Detached by distance from their own people they generally are all for self and none for the adopted nation" (at 354-55). Aikins indicates, however, that U.S., United Kingdom, and French immigrants are not the subject of concern. 
hence, "Standard Solicitors' Tariffs."74 Even this was presented as being for the benefit of society in that it would create "a higher type of barrister and advocate, well skilled in the law, gentlemanly in conduct, kindly disposed to his fellow practitioners and of a public spirit." 75 This was to be reinforced by "the frequent meetings of the members of each of the Provincial Bars." 76 These "official law and Bar societies" were, he said, invaluable "bulwarks protecting the people against incompetent and unscrupulous men posing as lawyers, and thus guarding the honour of the profession."77

Similarly, and for much the same reasons, it was necessary to clearly demarcate lawyers from "unauthorized practitioners." These latter would not have the same education as lawyers, would not be subject to the same ethical codes, and therefore could not be trusted to provide competent service to their clientele. Aikins warned that those "without suitable qualifications would batten on a too credulous and unsuspecting people," and called upon the Benchers of the various law societies to adopt "the best methods and ways possible" to "fulfil the statutory and traditional obligations cast upon them and protect the profession from encroachment upon its sphere." 78

There was a symmetry and mesh of components here, a vision of professionalism cut of whole cloth.

\title{
XII. Keystone of Social Cohesion
}

The rhetoric of service infused professional discourse during and after the Great War. ${ }^{79}$ Lawyers were said to be qualified by training, experience, and commitment to service, as "natural leaders of the people in public affairs." ${ }^{\circ 0}$ As such they could provide an antidote to various undesirable ideologies which were then in circulation:

\begin{abstract}
A special duty rests upon our profession both on the Bench and at the Bar, for we are the agents and ministers of the law.... Through a general neglect of that service in our country of popular suffrage our people are in imminent danger of the despotism not so much of individuals as of classes, organized on the principle of every one for himself. ${ }^{81}$
\end{abstract}

The whole package of legal professionalism was conceived as a bulwark against social unrest, despotism, and class warfare. ${ }^{82}$ It was hoped that "greater unity of the profession would lead

\footnotetext{
Aikins, "Ethics, Education and Emolument," supra note 69 at 336.

Ibid. at 338 .

Ibid.

Ibid.

Archive of MB Legal-Judicial History (University of Manitoba), File \#P1534, “Aikins is Again Head of Governing Bodies" (28 August 1928) (Summary 2nd Annual Conference on Benchers) 2. In furtherance of this vision, the Manitoba Law Society's proactive "Committee on Encroachments" recommended investigating the areas in which the public should look to lawyers for service.

79 See e.g. Aikins, "Inaugural Address," supra note 59.

80 Canadian Bar Association, Proceedings at Fifth Annual Meeting, "The President's Address" (1920) 56 Can. L.J. 308 at 308 [emphasis added].

81 Ibid. at 309 [emphasis added].

82 A somewhat similar point is made with reference to U.S. developments by James C. Foster, who argues that the "bar association" movement was a deliberately "ideological" responses to the crises of U.S. capitalism. See Foster, supra note 4.
} 
to the much needed and greater unity in the thought and action among the peoples of Canada and to like mindedness and singleness of heart and soul in the interest of our country." ${ }^{83}$

Thus, it was cultural revolution first and foremost that Canadian lawyers sought. The goal was to avert political disaster. More than anything else, the craving for national integration on such terms spurred lawyers toward modern "professionalization." Seeking to avert radical social change, they discovered their profession.

\section{Conclusion}

This vision of professionalism resonated at many levels with popular conceptions of appropriate social organization. Ironically, it was imbricated with the very modernity which, in other manifestations, its proponents resisted. This period, this time, and the peculiar circumstances relating to the opening of Canada's western empire provided the habitat from which emerged the form of professionalism which Canadian lawyers now take for granted. The vision of social life which it incorporates, however, has little currency in our time or among contemporary lawyers.

The conclusions to be drawn from this can be traced along two axes. The first is in relation to theories of professionalism, the second in relation to wider issues in cultural history.

\section{A. Theories of Professionalization}

The theories of professionalization which have enjoyed currency during the past 50 years have fallen into functionalist or "rational choice" camps (the latter manifesting itself in both "market control" and "work jurisdictions" variants). Two of the pre-eminent theorists of legal professionalism, Terence $C$. Halliday and Lucien Karpik, have described these approaches as focusing on (1) the achievement of "a service relationship," (2) "the monopolistic strategy of extracting market rent and thus social privilege," and (3) "the deployment of knowledge for the creation and defence of work jurisdictions as a way to define boundaries between work domains. ${ }^{" 84}$ Each approach is inadequate, they assert, on account of what each of them overlooks: "politics." 85

Certainly, the history of lawyers' professionalization in Canada provides strong support for the critique of both functionalist approaches premised on "client-service" and narrowly economic interpretations of professionalism. ${ }^{86}$ The "market control paradigm" and its cousins, even when qualified and re-worked to the highest level of sophistication, cannot adequately account for the very obvious non-market motivations of legal professionals who struggled to

83 Supra note 80 at 308 [emphasis added].

84 Halliday \& Karpik, "Politics Matter," supra note 19 at 15.

85 Ibid.

86 Cf. Stuart A. Scheingold, "Taking Weber Seriously: Lawyers, Politics, and the Liberal State" (1999) 24 Law \& Soc. Inquiry 1061; Michael Burrage, "Escaping the Dead Hand of Rational Choice: Karpik's Historical Sociology of French Advocates" (1999) 24 Law \& Soc. Inquiry 1083. 
create their profession. ${ }^{87}$ Nor can it account for the very important non-market effects of legal professionalism. Much more is at stake than who gets what portion of the economic pie. To the extent that Canada's legal professionals re-created their profession in an attempt to stave off political and social change, to warp discourses of politics and civic life by confining them in "acceptable" channels, their project can seem to carry an almost conspiratorial and antidemocratic import of far greater significance than "market control" ordinarily implies. ${ }^{88}$

Canadian lawyers clearly had political objectives of sorts in mind as they went about the work outlined above. Because of this, their story might be taken as buttressing an emerging interpretive frame which postulates a necessary and causal relationship between lawyering and the rise of western political liberalism. ${ }^{89}$ There can be little doubt that "the politics of lawyers directly engage one of the great ideological and institutional movements of the past several centuries - the construction of political liberalism. ${ }^{" 90}$ Equally, there can be little doubt that the lawyers who created the twentieth-century Canadian common law legal professions were "liberals" in the broad sense. They were committed to private property (within limits), individual freedom (within limits), laissez-faire (within limits), a moderate state, civil society, and a rights-based form of citizenship which encompassed both British constitutionalism and the rule of law. By the same token however these lawyers do not appear in quite so heroic and unambiguous a guise as those who struggled to create political liberalism in more authoritarian places. ${ }^{91}$ Their story points to an unseemly under-side to liberalism which is not always immediately apparent. Not all lawyers have played key roles in the overthrow or containment of absolutist regimes and it is dangerous to build theory on a few well-documented case studies which may turn out to be aberrational. Political theorists have properly emphasized that the success of liberal governance rests on the pre-adaptation of subjects to self-governance. It is dependent, at least in the context of large "nation states," on mechanisms of social control which contain difference. The modern organization of the legal profession, to be blunt, originated in desires to contain diversity, to exclude inappropriately socialized individuals who were deemed unsuited to professional life. Where long-standing tradition or custom does not "naturally" contain difference substitutes are found. Cultural projects operating through temperance societies, welfare, state, education, policing, and professions are the result. Legal professionalism, like moral regulation movements, can be a manifestation of "an anxiety of freedom that haunts modern liberal forms of rule" where there "is no 'natural' system of

Hurlburt, supra note 34, lends some support to what he calls the "honour" model of legal professionalism as developed by Michael Burrage, "From a Gentleman's to a Public Profession: Status and Politics in the History of English Solicitors" (1996) 3 International Journal of the Legal Profession 45.

88 Cf. Foster, supra note 4 at 47 :

But the political importance of lawyers' trade association involves [sic] is considerably more than restricting competition.... The American bar's prerogatives are not simply occupational.... By insisting we see through all that lawyers professed, to the 'proprietary' motives behind their words, Auerbach directs our attention away from the very real imperative that both conservative and progressive lawyers perceived to shore up the hegemony of the liberal-capitalist steering principles underlying their power. What elite lawyers said is as significant as what they did.

Terence C. Halliday \& Lucien Karpik, Politics Matter: A Comparative Theory of Lawyers in the Making of Political Liberalism (Chicago: American Bar Foundation, 1995); Scheingold, supra note 86. Terence C. Halliday, "The Politics of Lawyers: An Emerging Agenda" (1999) 24 Law \& Soc. Inquiry 1007 at 1010.

91 See various of the contributions to Halliday \& Karpik, Rise of Western Political Liberalism, supra note 19. 
order." ${ }^{92}$ It is important to take into account this seemingly anti-democratic zone of professional activity, as well as the more obviously "liberal" contributions of individual lawyers and (less often) organized legal professions alike.

\section{B. LaWyers' Histories and CUltural History}

The second general conclusion that might be suggested by the example of legal professionalism in twentieth-century Canada is with regard to the relationships between professional forms and cultures. In this zone of liberal lawyers' "illiberal" activity it is cultural projects which come to the fore. They do so only in part to advance a political vision as such. We do well in this area to heed Alan Hunt's caution against taking conceptual categories too seriously:

\footnotetext{
We conventionally make distinctions, such as those between social, economic and moral realms; such categories are useful, even necessary, so long as we do not fall into the trap of imagining that these terms create real separations as if there is some field, realm or space that is exclusively social, moral or economic.... Our conceptual distinctions are elaborated for analytical purposes only; in the real world they are always found in complex connection with other elements. ${ }^{93}$
}

The founding fathers of modern legal professionalism in Canada knew full well that their profession, their personal ethics, religion, economic beliefs, and political convictions were bound together in some fashion. It was not an absolutist binding together however. For some purposes Baptists or Jews or Catholics could be tolerated, just as in politics disagreements between Liberals and Conservatives were both legitimate and genuine. Nonetheless, a cultural web held the whole together and most leading lawyers would have understood the urges which led Michel Foucault to describe one project of western states as being to "constitute the populace as a moral subject." ${ }^{" 44}$ This was no idle philosophy in their time and their place. In common cause with other prominent Canadians acting in many realms, it was their passion, their purpose, and the essence of their commitment to public service.

What is interesting in the work of the legal profession is the extent to which lawyers combined agendas which were explicitly moral and reforming with a profound restructuring of their profession. Their efforts to reform the curriculum of formal legal education, for example, is not altogether dissimilar from near contemporaneous efforts to introduce public schooling, to reform private boys schools, to educate imperial civil servants, or to fashion universities anew so as to meet the needs of a changing world. ${ }^{95}$ Though it is less immediately obvious perhaps with respect to their desire to attain self-regulation, monopoly, professional independence, and plenary disciplinary powers, these too were directed to "cultural" ends. They built structures on cultural foundations, drawn to blue-prints of moral origin.

Alan Hunt, Governing Morals: A Social History of Moral Regulations (New York: Cambridge University Press, 1999) at 215.

$94 \quad$ Michel Foucault, Power/Knowledge: Selected Interview and Other Writings, 1972-1977, ed. by Colin Gordon (Brighton: Harverster Press, 1980) at 41. 
This, of course, is a limited conclusion. To assert that Canadian legal professionalism originated in cultural projects in the early twentieth century is not to assert that all legal professions, everywhere, always have originated in these ways (only imperial centres and obviously important places - such as London, New York, Los Angeles, or Paris - can plausibly hope to turn their parochialisms into social theory).

Moreover, the argument that structures emerge from deliberate, self-conscious agency cannot be made at all places and all times. Some professional structures may indeed have important origins which are lost in the mists of time and others may accrete slowly in ad hoc response to periodic crises (the English bar comes to mind in both categories). It is also undoubtedly the case that much cultural, economic, and political change takes place within frameworks provided by more or less durable structures. The late twentieth-century legal profession, for example, leaves little room for the rhetoric of moral reform. No contemporary lawyer can adopt the role of a "high priest" of law, just as no university law teacher could now seriously adopt as his or her mission the inculcation of the virtues of British gentlemanliness.

Even modestly understood, however, the findings reported here are not de minimis. They direct our attention to questions of cultural agency and structural revolution that are too easily overlooked. They suggest connections between market control, political lawyering, culture, liberalism, and professionalism that have yet to be adequately explored. 